\title{
Bioactivation of zearalenone by porcine hepatic biotransformation
}

\author{
Hassan MALEKINEJAD, Roel Franciscus MAAS-BAKKER, \\ Johanna FINK-GREMMELS* \\ Department of Veterinary Pharmacology, Pharmacy and Toxicology, Faculty of Veterinary Medicine, \\ Utrecht University, Yalelaan 16, 3508 TD Utrecht, The Netherlands
}

(Received 18 June 2004; accepted 4 April 2005)

\begin{abstract}
Zearalenone (ZEA) is a resorcylic acid lactone derivative produced by various Fusarium species that are widely found in food and feeds. The structure of zearalenone is flexible enough to allow a conformation able to bind to mammalian oestrogen receptors, where it acts as an agonist. Using oestrogen-dependent Human Breast Cancer (MCF-7) cells, the oestrogenic activity of zearalenone and its derivatives were compared using $17 \beta$-oestradiol as a positive control. The results obtained demonstrate that the oestrogenic potency of ZEA derivatives could be ranked in the following order: $\alpha$-zearalenol $>\alpha$-zearalanol $>$ zearalenone $>\beta$-zearalenol. Since pigs have been reported to be among the most sensitive animal species, biotransformation studies with pig liver subcellular fractions were conducted. These studies indicated that $\alpha$-zearalenol is the main hepatic metabolite of zearalenone in pigs, and it is assumed that $3 \alpha$ - and $3 \beta$-hydroxysteroid dehydrogeneases are involved in the hepatic biotransformation, since the formation of $\alpha$-zearalenol and $\beta$-zearalenol could be inhibited by prototypic substrates for either enzyme. The bioactivation of ZEA into the more active $\alpha$-zearalenol seems to provide a possible explanation for the observed high sensitivity of pigs towards feedingstuffs contaminated with the mycotoxin.
\end{abstract}

zearalenone / MCF-7 cells / oestrogenic effects / biotransformation / pigs

\section{INTRODUCTION}

Human and animal diets may contain several non-steroidal weakly oestrogenic compounds that are either produced by plants (phyto-oestrogens) or by fungi (myco-oestrogens). The most important myco-oestrogen is zearalenone (ZEA), [6(10-hydroxy-6-oxo-trans-1-undecenyl)- $\beta$ resorcylic acid], a non-steroidal compound mainly produced by the fungal species Fusarium graminearum and Fusarium culmorum. It is one of the most frequently occurring contaminants of corn and cornderived plants and it has also been detected in cereals such as barley, rice, oats, rye, sorghum, soy beans and wheat $[8,28]$.

Following ingestion with feed, zearalenone is rapidly absorbed from the gastro-intestinal tract, and oral availability is estimated to reach $80-85 \%$ in monogastric species. In the liver, zearalenone is reduced to the isomeric $\alpha$ - and $\beta$-zearalenols ( $\alpha$-ZOL and $\beta-Z O L)$, a reaction that competes with glucuronidation of the parent molecule. Previous data indicated that the ratio

\footnotetext{
*Corresponding author: J.Fink@ vfft.vet.uu.nl
} 


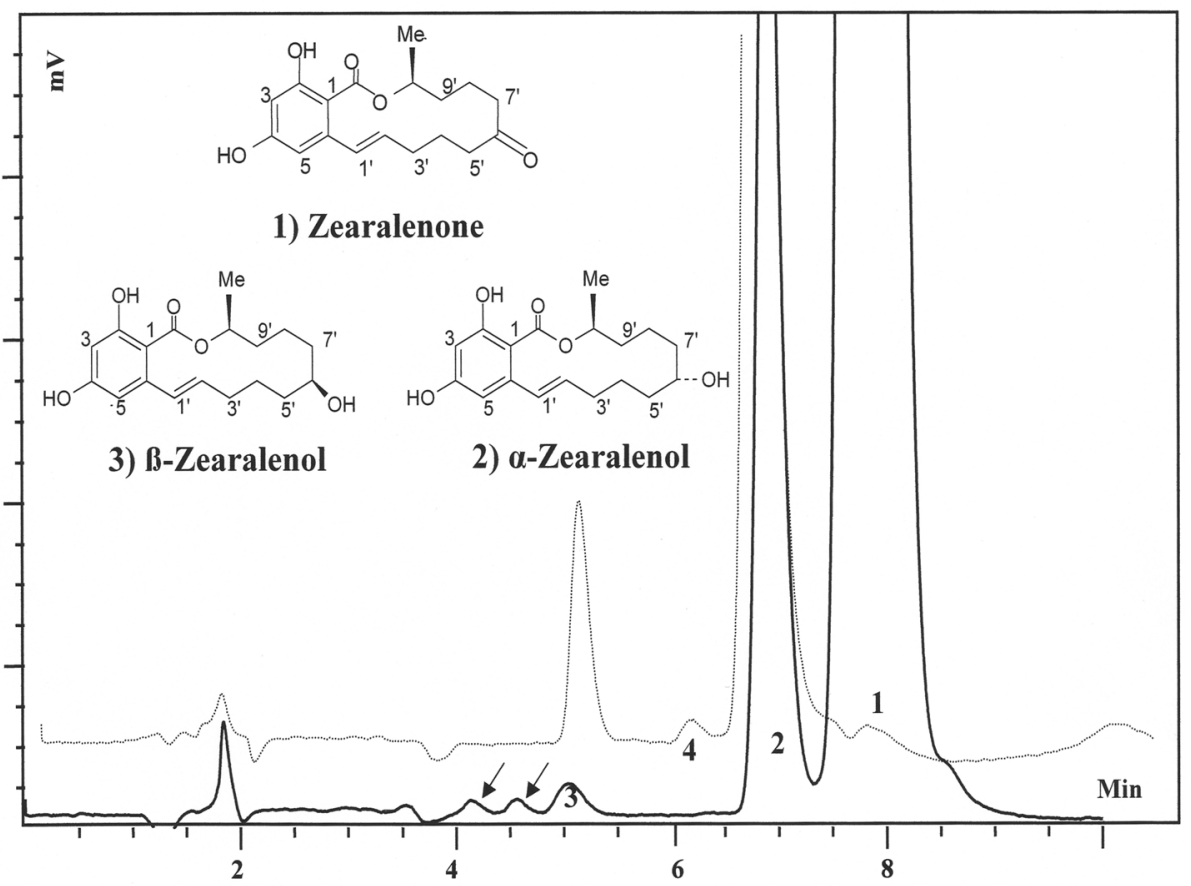

Figure 1. Chemical structures of zearalenone and its metabolites, and an HPLC profile with ZEA (1), $\alpha$-ZOL (2), $\beta$-ZOL (3), and (4) $\alpha$-ZAL. The grey chromatogram depicts the mixture of the standards, the black chromatogram is a representative chromatogram of samples (pig liver microsomes incubated with zearalenone (for details see Materials and methods section).

between $\alpha$-ZOL and $\beta$-ZOL varies considerably among species, as for example pigs seem to form predominantly $\alpha$-ZOL, whereas in cattle predominantly $\beta$-ZOL formation is observed. The chemical structures of ZEA and its major metabolites are shown in Figure 1. In some animal species, including cattle, goats, sheep and horses, a further reduction of $\alpha$-ZOL into the corresponding $\alpha$-zearalanol (zeranol) and $\beta$-zearalanol (taleranol) takes place in vivo. Whether or not hepatic metabolism contributes to this second methylation step remains to be elucidated [27]. The possible biotransformation of zearalenone into zeranol is of particular interest, since in non-European countries zeranol might be used as a growth promoter in cattle, whereas it is strictly inhibited in Europe (Council Directive 96/22/EC).
ZEA as well as many of its metabolites act as oestrogen receptor (ER) agonists. They can bind competitively to oestrogen receptors located in the uterus, mammary gland, liver and hypothalamus, as demonstrated in various species [21, 24], and the consumption of contaminated feed has been associated with clinical signs of hyperoestrogenism in pigs and other animal species $[8,13,25]$. Pigs appear to be especially sensitive to the oestrogenic effects of ZEA and adverse affects in sexually mature pigs include decreased fertility, ovarian atrophy, prolonged oestrus, oedematous swelling and reddening of the vulvae, prolapsed uterus and rectum. In piglets, stillbirth, reddening and swelling of the vulva, nipples and the prepuce as well as necrosis of the tail have been described [7, 8, 41, 42]. 
In the present study, the oestrogenic activity of ZEA and its metabolites is compared to that of $17-\beta$-oestradiol in a bioassay. In this assay, proliferation of oestrogen-dependent human breast cancer cells (MCF-7 cells) is used as a marker to assess oestrogenic potency. Since pigs are known to be very susceptible to the adverse effects of ZEA, the biotransformation of this mycotoxin was investigated in vitro using subcellular fractions of the pig liver to assess the ratio of the individual metabolites.

\section{MATERIALS AND METHODS}

The test compounds $17 \beta$-oestradiol $\left(\mathrm{E}_{2}\right)$, zearalenone (ZEA), $\alpha$-zearalenol ( $\alpha$-ZOL), $\beta$-zearalenol $(\beta$-ZOL), zeranol $(\alpha-\mathrm{ZAL})$, activated charcoal, and MTT [(3-4,5dimethylthiazol-2-yl)-2,5-diphenyltetrazolium bromide)] were purchased from Sigma Chemical Co. (St. Louis, MO, USA). DMEM medium was obtained from GIBCO (Aickland, United Kingdom), and T77 dextran was purchased from Amersham Pharmacia Biotech (Upsala, Sweden). MCF-7 cells were obtained from ECACC (European Collection of Cell Cultures). All test compounds were dissolved in absolute ethanol in order to prepare $100 \mu \mathrm{M}$ and $10 \mu \mathrm{M}$ stock solutions, respectively. All solutions were stored at $4{ }^{\circ} \mathrm{C}$ prior to use.

\subsection{Bioassay for oestrogenic activity of ZEA and its metabolites}

\subsubsection{Cell cultures}

Human breast cancer cells (MCF-7) were cultured in DMEM without phenol red, supplemented with $10 \%$ bovine calf serum (BCS), $1 \%$ penicillin (100 units/mL), streptomycin $(100 \mu \mathrm{g} / \mathrm{mL}), 1 \%$ L-glutamine, $1 \%$ sodium pyruvate $(100 \mathrm{mM})$, and $0.1 \%$ bovine insulin ( $1 \mathrm{mM})$, subsequently denoted as a complete DMEM medium. The cells were maintained as monolayer cultures in standard culture flasks, kept at $37{ }^{\circ} \mathrm{C}$ in a humidified atmosphere of $5 \% \mathrm{CO}_{2}$ in air. Every 4-5 days, the subcultures were obtained using trypsin.

\subsubsection{Preparation of charcoal-dextran- treated bovine calf serum (CD-BCS)}

Charcoal-Dextran (CD) was used to remove natural oestrogens from the BCS according to Ju et al. [20]. Briefly, activated charcoal (5 g, Norit-Sigma) was mixed with 0.5 g T77 dextran (Pharmacia, Uppsala, Sweden), and the mixture was suspended in $100 \mathrm{~mL}$ demineralised water. After 3 times washing by centrifugation $(2500 \mathrm{rpm}$, $20{ }^{\circ} \mathrm{C}$, and $3 \mathrm{~min}$ ), the supernatant was removed and $5 \mathrm{~mL} \mathrm{BCS}$ was added to $5 \mathrm{~mL}$ of the $\mathrm{CD}$ suspension. Following mixing on a roller-plate for $1 \mathrm{~h}$, the suspension was centrifuged ( $2500 \mathrm{rpm}$ for $20 \mathrm{~min}$ ) and the supernatant was filter-sterilised (Nalgene SFCA membrane, $0.22 \mu \mathrm{m}$ ). Aliquots of the CD-BCS obtained were stored at $-20{ }^{\circ} \mathrm{C}$ in glass tubes until use.

\subsubsection{Oestrogen-dependent cell proliferation}

MCF-7 cells were harvested by trypsinisation of stock cultures and were re-cultured in 75-mm flask and incubated in $37^{\circ} \mathrm{C}$ and $5 \% \mathrm{CO}_{2}$. After $72 \mathrm{~h}$ the medium was removed and replaced by complete DMEM without phenol red that contained $10 \%$ DCBCS. In the first set of the experiments, MCF-7 cells were then seeded in 96-well cell culture plates with different densities (2 500, 5 000, 10000 , and 20000 cells/ well) and incubated with $17-\beta$ oestradiol for three different time periods $(96,120$, and $144 \mathrm{~h}$ ) in order to assess oestrogen dependent cell proliferation as compared to solvent treated controls by means of the MTT assay. Each experiment was conducted in triplicate, and the data represent means \pm SD from three independent experiments. 


\subsubsection{Assessment of mycoestrogen potency by the MCF-7 cell proliferation assay}

As described above, MCF-7 cells were seeded in 96 well-culture plates ( 10000 cells/ well in $200 \mu \mathrm{L}$ medium). After $24 \mathrm{~h}$, the medium was removed and replaced with supplemented DMEM containing 10\% CDFCS and different concentrations of the test chemicals including $\mathrm{E}_{2}\left(10^{-3}-10^{4} \mathrm{pM}\right)$, ZEA and its derivatives $\left(10^{-3}-10^{7} \mathrm{pM}\right)$; $\alpha-Z A L$ was included as second positive reference due to its known oestrogenic activity $[22,23,27]$. After 6 days of incubation at $37{ }^{\circ} \mathrm{C}$ and $5 \% \mathrm{CO}_{2}$, the MTT-assay was conducted and data are compared with the corresponding solvent-treated controls. The data represent the results of three independent experiments each conducted in triplicate. $\mathrm{EC}_{50}$ values were calculated using non-linear regression analysis (Win Nonline 4.1., Pharsight, North Carolina, USA).

\subsubsection{MTT Test}

Cell proliferation was quantified by the colorimetric MTT [3-(4,5-dimethylthiazol-2yl)-2,5-diphenyltetrazolium bromide] assay. This assay measures the reduction of dimethylthiazol diphenyl tetrazolium bromide (MTT; stock solution $3 \mathrm{mg} / \mathrm{mL}$ dissolved in PBS) to formazan by the mitochondrial enzyme succinate dehydrogenase. This reduction capacity reflects the number of viable cells, hence the MTT assay is used for both the assessment of cytotoxicity and the demonstration of cell proliferation. Following the described incubation period, the medium was discarded and $0.2 \mathrm{~mL}$ MTT solution was added to the cells. After $3 \mathrm{~h}$ incubation at $37^{\circ} \mathrm{C}$ the MTT solution was discarded and the intracellular purple insoluble formazan was solubilised by adding $100 \mu \mathrm{L} /$ well of lysis buffer $(0.5 \%$ sodium dodecyl sulphate, $36 \mathrm{mM} \mathrm{HCl}$, and isopropanol acid). Following careful mixing, the optical density (OD) was measured at $594 \mathrm{~nm}$ using a micro plate reader (BIORAD Model 3550). Cell proliferation rate was expressed as the percentage of nontreated controls as follows: $\mathrm{A}_{595}$ treated cells/A ${ }_{595}$ of control) $\times 100$.

\subsection{Biotransformation of ZEA by subcellular fractions derived from porcine livers}

\subsubsection{Preparation of liver subcellular fractions}

Immediately after slaughter, liver specimens from four male pigs (Great Yorkshire $\times$ Dutch Landrace), aged approximately 12 weeks, and weighing between 30 and $35 \mathrm{~kg}$, were collected, cut into small pieces, and rinsed three times with ice-cold saline to remove excess blood. The subcellular fractions were prepared according to Rutten et al. [34]. Briefly, two volumes of KCL $(1.15 \%)$ and EDTA $(0.1 \mathrm{mM})$ solution were added to a tissue sample and the mixture was homogenised in a Potter-Elvehjem apparatus with a Teflon pestle. The homogenate was then centrifuged at $9000 \mathrm{~g}$ at $4{ }^{\circ} \mathrm{C}$ for $30 \mathrm{~min}$ and an aliquot of the supernatant was collected as the post-mitochondrial (S9) fraction. The remaining sample was centrifuged at $100000 \mathrm{~g}$ at $4{ }^{\circ} \mathrm{C}$ for $90 \mathrm{~min}$ in order to obtain the microsomal fraction. After centrifugation, the supernatant was discarded and the pellet was carefully dissolved in the same volume of phosphate buffer (0.05 M; pH 7.4) with glycerol (20\%), and then homogenised with an ultra-turrax. The individual fractions of the four pigs were pooled and stored at $-70^{\circ} \mathrm{C}$ until use. Protein concentrations of the microsomal and the S9-fractions were determined according to Lowry et al. [26].

\subsubsection{Incubations with subcellular fractions}

In order to measure the biotransformation products, different concentrations of ZEA were added to the reaction mixtures of $250 \mu \mathrm{L}$, containing either pooled liver microsomes $(0.375 \mathrm{mg}$ protein per $\mathrm{mL})$ or 
the post-mitochondrial fraction of the liver (1.25 mg protein/mL) and supplemented with NADPH $(0.5 \mathrm{mM})$ in a final volume of $250 \mu \mathrm{L}$ phosphate buffer $(50 \mathrm{mM}$, $\mathrm{pH}$ 7.4). The samples were incubated in a shaking water bath at $37^{\circ} \mathrm{C}$ for $30 \mathrm{~min}$. The reaction was stopped by transferring the samples to an ice-cold environment followed by extraction with chloroform $(1.25 \mathrm{~mL})$. One millilitre of the organic phase was collected and evaporated to dryness under a stream of $\mathrm{N}_{2}$. The residue was redissolved in the mobile phase. Analysis of the enzyme kinetics revealed under these conditions an enzyme velocity $\left(\mathrm{V}_{\max }\right)$ of $953 \pm 75$ pmol.mg/min and $173 \pm$ $30 \mathrm{pmol} . \mathrm{mg} / \mathrm{min}$ for the $\alpha-Z O L$ and $\beta$-ZOL formation in liver microsomes, and $401 \pm$ $38 \mathrm{pmol} / \mathrm{mg} / \mathrm{min}$ and $80 \pm 7.7 \mathrm{pmol} . \mathrm{mg} / \mathrm{min}$ for the formation of $\alpha-Z O L$ and $\beta-Z O L$ in the post-mitochondrial fraction, respectively.

\subsubsection{Inhibition studies}

In order to assess the involvement of $3 \alpha-$

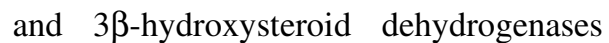
( $3 \alpha$ and $3 \beta-H S D)$ in the biotransformation of ZEA, $5 \alpha$-anderostanedione (5 $\alpha$-AND) as the endogenous substrate of $3 \alpha-\mathrm{HSD}$, and pregnenolone as the endogenous substrate for $3 \beta$-HSD were added to the incubation mixture at increasing concentrations $(50,100,250,500$ and $1000 \mu \mathrm{M})$, whereas the concentration of ZEA $(1000 \mu \mathrm{M})$ remained constant. These incubations were conducted with porcine liver microsomes in the presence of NADPH as the co-factor and at $\mathrm{pH} 7.4$ for $30 \mathrm{~min}$. Data were compared to control incubation conducted with ZEA only.

\subsubsection{HPLC determination and confirmation of ZEA metabolites}

ZEA and its metabolites were determined by high-performance liquid chromatography (HPLC) according to Trenholm et al. [39]. The chromatographic system consisted of an auto sampler (Gynkotek Autosampler Model GINA 50, Separations
Analytical Instruments BV, Hendrik Ido Ambacht, The Netherlands) and dual pumps (Gynkotek High Precision Pump Model 300, Separations Analytical Instruments BV, Hendrik Ido Ambacht, The Netherlands). Fifty microlitres of the extracted sample was injected onto a LUNA $5 \mu \mathrm{C} 18$ $(150 \times 4.60 \mathrm{~mm}$, Phenomenex $)$ column. The mobile phase consisted of a mixture of methanol-water (70:30, v/v) eluted at a flow-rate of $0.8 \mathrm{~mL} / \mathrm{min}$. Detection occurred by means of a fluorescence detector (Jasco Fluorescence Detector Model FP-920, Separations Analytical Instruments BV, Hendrik Ido Ambacht, The Netherlands), set at an excitation and emission wavelength of 236 and $418 \mathrm{~nm}$, respectively. ZEA and its metabolites were quantified by measuring peak areas, and comparing them to the relevant calibration curves.

\subsection{Statistical analysis}

All results are presented as means \pm SD. Differences in the cell proliferation between the control and treatment groups and differences between the control and treated groups in ZEA biotransformation in the presence of different competitors were evaluated with one-way ANOVA. Differences between the amounts of produced metabolites by either the microsomal or the post-mitochondrial fractions were analysed by a student $t$-test. $P<0.05$ was considered as significant.

\section{RESULTS}

\subsection{Bioassays with MCF-7 cells}

Standardisation of the bioassay with MCF-7 cells has to address a number of variables including the cell number, incubation time and non-specific responses exerted by oestrogenic compounds present in commercial cell culture medium supplements. Initial studies indicated that the optimal density of MCF-7 cells in a 96-well tissue culture plate is $1 \times 10^{4}$ cells/well (Fig. 2), 


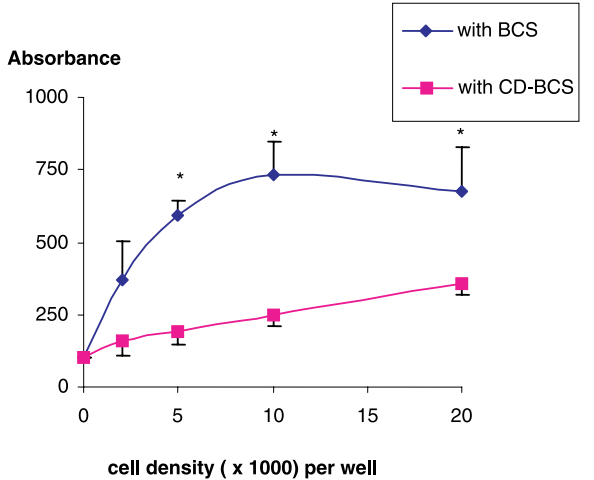

Figure 2. Effect of serum composition on MCF7 cell proliferation: The cells were left to grow for 6 days and proliferation was measured by an MTT test. Optical density of control incubations was set to 100 , and data are expressed as the percentage of this control. Individual data points represent the mean \pm SD of three independent experiments conducted in triplicate.

since at this concentration a measurable but not-significant cell proliferation could be measured in the control samples.

Also in this study, the difference between native BCS and charcoal-stripped CD-BCS could be seen, since there was a significant higher proliferation rate of cells incubated with BCS as compared to the cells incubated with CD-BCS. This difference is considered to be attributable to residual amounts of natural oestrogens present in BCS. In the presence of CD-BCS serum cell proliferation was minimal $(P<$ 0.001 ; Fig. 2). These findings implied that all assays have to be conducted with stripped, oestrogen-deprived serum.

A second set of experiments was conducted to assess the optimal incubation time. Data shown in Figure 3 indicate that the late exponential phase of cell proliferation in response to the exposure to graded concentrations of the positive control $17 \beta$ oestradiol is reached after $144 \mathrm{~h}$. This time period was subsequently used in all further experiments. Moreover, it could be demonstrated that $17 \beta$-oestradiol (see also Fig. 4A) induced a maximal proliferation rate at a

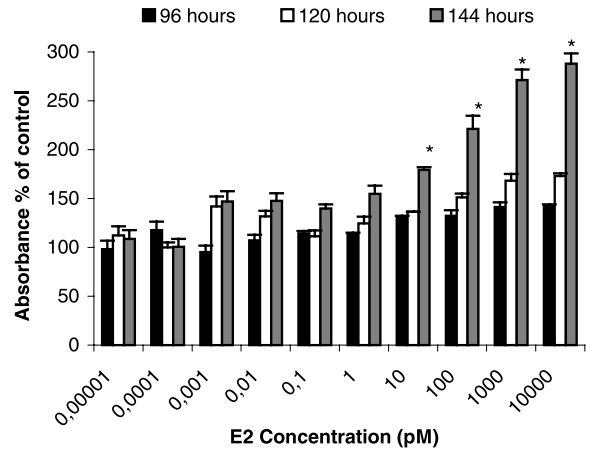

Figure 3. Dose-response curve of $17 \beta$-oestradiol at various treatment times: $10^{4}$ cells/well were treated with various concentrations of $17 \beta$ oestradiol and incubated for different time intervals. Cell proliferation was assessed by the MTT test. Data points represent the mean \pm SD of three independent experiments conducted in triplicate.

concentration of $10^{3} \mathrm{pM}$. The calculated $\mathrm{EC}_{50}$ value corresponded to $2.8 \mathrm{pM}$.

\subsection{Effect of ZEA and its derivatives on cell proliferation}

Proliferation of the MCF-7 cells was analysed in the presence of ZEA and its metabolites. The data in Figure 4B show that ZEA and its reduced metabolites significantly enhance the proliferation of MCF-7 cells. The following $\mathrm{EC}_{50}$ values were calculated: $49.9,105.6,1638.7$, and $20007.9 \mathrm{pM}$ for $\alpha$-ZOL, $\alpha$-ZAL, ZEA, and $\beta$-ZOL, respectively, implying that the most potent zearalenone derivative, $\alpha-Z O L$ is about 20 times less potent than $17 \beta$ oestradiol.

\subsection{ZEA metabolism by liver subcellular fractions}

Following the incubation of either porcine microsomes or post-mitochondrial fractions with different concentrations of ZEA, the chloroform-extracted samples were subjected to HPLC analysis and ZEA 
A)

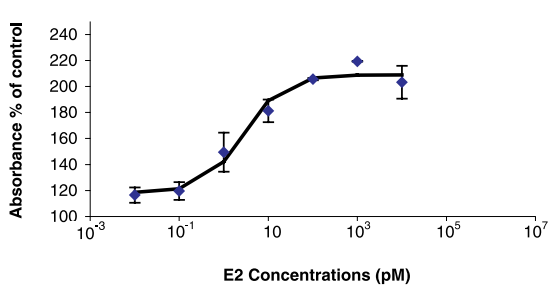

B) $\longrightarrow$ ZEA $-\frac{a}{-1}-$ a-zol $\cdots \Delta \cdot-b$-zol $-* *$ a-zal

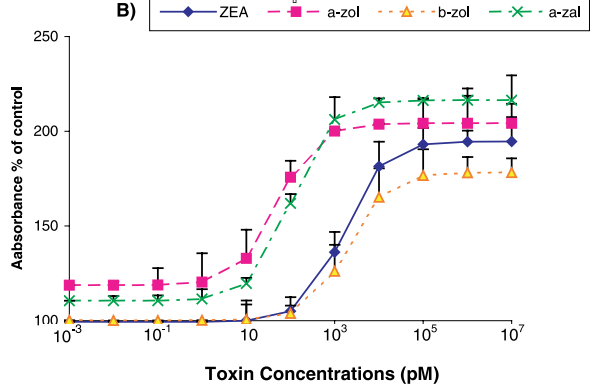

Figure 4. Dose-response curves of (A) $17 \beta$ estradiol, and (B) ZEA, $\alpha-Z O L, \beta-Z O L$, and $\alpha$-ZAL in the MCF-7 bioassay. Data points represent the mean $\pm \mathrm{SD}$ of three independent experiments conducted in triplicate.

(peak 1), as well as $\alpha-Z O L$ (peak 2) and $\beta$-ZOL (peak 3) were quantified according to the respective standard curves. Two other unknown minor metabolites were detected as presented in Figure 1, but could not be identified.

As shown in Tables I and II, the major metabolite of ZEA formed by pig liver microsomes and the liver post-mitochondrial fraction was $\alpha$-ZOL. Only at low concentrations of ZEA $(<100 \mu \mathrm{M})$ did the amount of $\beta$-ZOL exceed that of $\alpha-Z O L$. A comparison of the biotransformation capacity in the microsomal fraction with that of the post-mitochondrial fraction indicated a higher biotransformation capacity in the microsomal fraction. The ratio of $\alpha-\mathrm{ZOL} /$ $\beta$-ZOL, however, was higher in the incuba- tion with the post-mitochondrial fraction as compared to incubations with the microsomal fraction. The absolute amount of metabolites formed by either the microsomal or the post-mitochondrial fraction differed significantly $(P<0.001)$.

\subsection{Inhibition of the biotransformation of Zearalenone by endogenous substrates for $3 \alpha$ - and $3 \beta$-HSD}

In order to demonstrate that $3 \alpha-$ and $3 \beta$ HSD are indeed involved in the hepatic biotransformation of ZEA and subsequently in the formation of $\alpha$ - and $\beta$-ZOL, porcine liver microsomes were incubated with ZEA $(1000 \mu \mathrm{M})$ in the presence of endogenous substrates for either $3 \alpha-\mathrm{HSD}$ or $3 \beta$-HSD. The results summarised in Figure $5 \mathrm{~A}$ show that the NADPH-dependent biotransformation of ZEA into $\alpha$-ZOL was significantly inhibited by $5 \alpha$-AND and PGN. This inhibition was concentrationdependent. In contrast, biotransformation of ZEA into $\beta$-ZOL by porcine liver microsomes was only inhibited in the presence of PGN at concentrations higher than $250 \mu \mathrm{M}$. Incubations with increasing concentrations of $5 \alpha$-AND did not significantly inhibit $\beta$-ZOL formation (Fig. 5B).

\section{DISCUSSION}

One of the most reliable bioassays to assess the oestrogenic activity of natural, semi-synthetic and synthetic chemical compounds measures the cell proliferation of the human breast cancer cells MCF-7 [3,9]. MCF-7 cells are known to express both types of oestrogen receptors, and cell proliferation depends on the presence of agonists to these receptors. This assay, also denoted as the E-screen, was applied with minor modifications in the current study, in order to compare the effects of ZEA and its hepatic metabolites with those induced by the synthetic growth promoter $\alpha$-zearalanol or the natural agonist $17 \beta$-oestradiol. 
Table I. Metabolism of ZEA by pig liver microsomes and ratio of $\alpha-Z O L / \beta-Z O L$. Individual values represent the means \pm SD of three independent experiments.

\begin{tabular}{cccc}
\hline $\begin{array}{c}\text { ZEA Concentration } \\
(\mu \mathrm{M})\end{array}$ & $\begin{array}{c}\alpha \text {-zol } \\
(\mathrm{pmol} / \mathrm{min} . \mathrm{mg} \text { protein })\end{array}$ & $\begin{array}{c}\beta \text {-zol } \\
(\text { pmol/min.mg protein })\end{array}$ & Ratio $\alpha$-zol: $\beta$-zol \\
\hline 10 & $11.88 \pm 1.5$ & $64.74 \pm 38.79$ & 0.18 \\
25 & $37.02 \pm 5.7$ & $79.56 \pm 31.81$ & 0.46 \\
50 & $71.33 \pm 1.5$ & $86.36 \pm 13.19$ & 0.82 \\
100 & $170.97 \pm 7.4$ & $84.06 \pm 7.14$ & 2.03 \\
250 & $370.60 \pm 11.1$ & $189.31 \pm 41.13$ & 1.95 \\
500 & $586.69 \pm 111.4$ & $287.63 \pm 47.96$ & 2.03 \\
750 & $510.41 \pm 143.9$ & $251.43 \pm 53.55$ & 2.03 \\
1000 & $598.53 \pm 204.2$ & $362.92 \pm 35.24$ & 1.64 \\
1250 & $643.64 \pm 196.6$ & $426.56 \pm 15.98$ & 1.50 \\
1500 & $776.21 \pm 230.2$ & $521.06 \pm 17.38$ & 1.48 \\
1750 & $977.26 \pm 349.9$ & $658.99 \pm 162.19$ & 1.48 \\
2000 & $891.15 \pm 1.6$ & $697.86 \pm 111.58$ & 1.27 \\
\hline
\end{tabular}

Table II. Metabolism of ZEA by pig liver post-mitochondrial fraction and ratio of $\alpha-Z O L / \beta-Z O L$. Individual values represent the means \pm SD of three independent experiments.

\begin{tabular}{cccc}
\hline $\begin{array}{c}\text { ZEA Concentration } \\
(\mu \mathrm{M})\end{array}$ & $\begin{array}{c}\alpha \text {-zol } \\
(\mathrm{pmol} / \mathrm{min} . \mathrm{mg} \text { protein })\end{array}$ & $\begin{array}{c}\beta \text {-zol } \\
(\mathrm{pmol} / \mathrm{min} . \mathrm{mg} \text { protein })\end{array}$ & Ratio $\alpha$-zol: $\beta$-zol \\
\hline 10 & $4.8 \pm 2.8$ & $8.9 \pm 2.5$ & 0.53 \\
25 & $4.1 \pm 0.4$ & $23.4 \pm 3.7$ & 0.60 \\
50 & $18.5 \pm 14.5$ & $22.9 \pm 4.2$ & 0.80 \\
100 & $55.1 \pm 26.9$ & $38.2 \pm 7.0$ & 1.44 \\
250 & $128.5 \pm 60.5$ & $56.7 \pm 6.4$ & 2.26 \\
500 & $239.9 \pm 49.1$ & $87.3 \pm 17.5$ & 2.74 \\
750 & $337.0 \pm 43.1$ & $108.0 \pm 4.0$ & 3.12 \\
1000 & $292.1 \pm 43.4$ & $110.4 \pm 20.8$ & 2.64 \\
1250 & $435.7 \pm 8.7$ & $154.2 \pm 11.1$ & 2.82 \\
1500 & $423.1 \pm 88.1$ & $152.2 \pm 21.4$ & 2.77 \\
1750 & $477.7 \pm 6.4$ & $197.7 \pm 42.8$ & 2.41 \\
2000 & $421.3 \pm 48.6$ & $170.9 \pm 51.1$ & 2.46 \\
\hline
\end{tabular}

A specific prerequisite for any assay designed to measure oestrogenic activity, is the avoidance of all oestrogenic compounds in the cell culture medium. Since natural BCS contains residual amounts of physiological oestrogens, demonstrated by the significant differences on cell proliferation between natural BCS and CD-BCS (see Fig. 2), the serum has to be stripped carefully prior to use by washing with activated charcoal and dextran. Moreover, in any cell proliferation assay, the optimal density of cells at seeding has to be estimated. To this end, a series of initial experiments was conducted with $17 \beta$-oestradiol showing that in 96 well plates MCF-7 cells reach the stationary phase of growth after $144 \mathrm{~h}$, when seeded at a density of $10^{4}$ cells per well. Although our results are in accordance with previously published data $[1,3,11]$, the exact assay conditions have to be established prior to the testing of new chemicals, since 

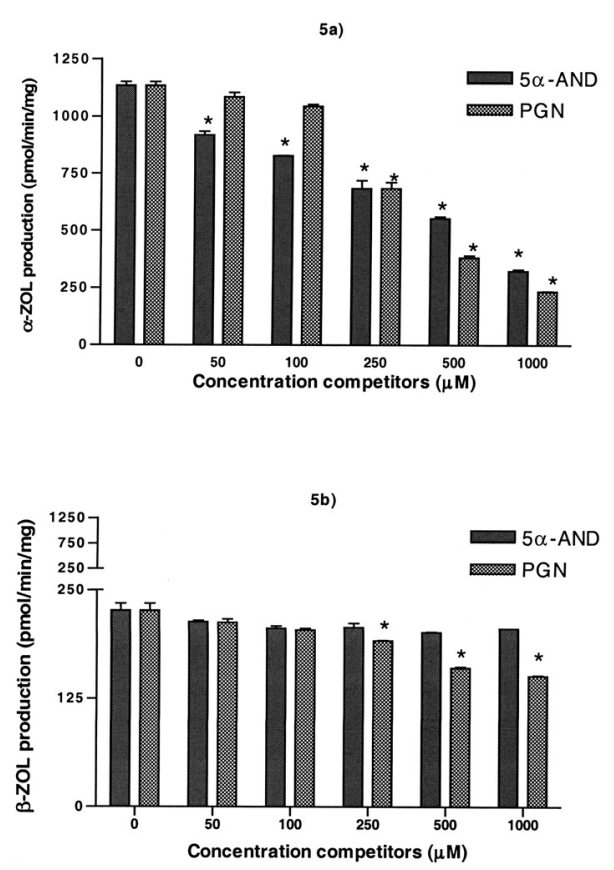

Figure 5. ZEA biotransformation by pig liver microsomes in the presence of endogenous substrates for $3 \alpha$ - and $3 \beta$-HSD: (a) $\alpha$-ZOL production and (b) $\beta$-ZOL formation in the presence of $5 \alpha$-androstanedione (5 $\alpha$-AND), and pregnenolone-(PGN).

the number of cell passages prior to the actual assay might influence cell proliferation rates as seen in SaOS cells [14], in MC3T3-E1 pre-neoblastic cells [18], in C-6 glioma cells [17], in LNCap prostatic adenocarcinoma cells [12], in Caco- 2 cells [6], and in rat mesangial cells [16].

Dose-dependent cell proliferation induced by oestrogenic compounds can be used to compare their relative oestrogenic activity. Based on the dose-response curves and the calculated $\mathrm{EC}_{50}$ values, the oestrogenic potency of ZEA and its derivatives can be ranked as follows: $\alpha-Z O L>\alpha-Z A L>$ ZEA $>\beta$-ZOL. The higher potency of $\alpha$ ZOL and $\alpha-Z A L$ as compared to parent ZEA and $\beta$-ZOL, reflect their higher affinity to the oestrogen receptors in $\mathrm{MCF}-7$ cells. These findings were in accordance with previous results, demonstrating that in a conventional eutopic assay, which assesses the increase of the organ weight of the juvenile uterus in mice or rats, the same ranking of the oestrogenic effects of ZEA and its metabolites was observed [35, 40].

The major advantages of an in vitro assay are its higher specificity and accuracy. In the eutopic assay, the uterus weight might be increased due to different factors, including among others inflammatory processes. Moreover, in vitro assays are independent of laboratory animals and allow the analysis of a wide range of concentrations of diverse contaminants. Hence, the MCF-7 cell proliferation assay has been widely used for the assessment of diverse oestrogenic compounds and is considered to be very specific [3, 10, 36, 37].

The agonistic property of ZEA to oestrogen receptors, inducing cell proliferation in MCF-7 cells, has been shown previously. Dees et al. [9] demonstrated that ZEA stimulates MCF-7 cells to enter the cell cycle by increasing the cyclin D1 protein levels, and activating cyclin-dependent kinase (Cdk)-2 resulting in the hyperphosphorylation of the retinoblastoma gene product [9]. These actions, in turn, lead to an increased rate of G1 to $\mathrm{S}$ phase transitions and mitosis. By inducing cell-cycle progression in MCF-7 cells, ZEA has anti-apoptotic properties [1].

In the intact animal, there are two main biotransformation pathways for ZEA. The reduction of ZEA by hydroxysteroid dehydrogenases (HSD) yields $\alpha$ - and $\beta$-zearalenol. In addition, both ZEA and the reduced metabolites are known to be conjugated to glucuronic acid in the presence of UDPGglucuronyl transferase, facilitating biliary and renal excretion $[4,5]$.

The reduction of ZEA resembles that of steroid metabolism catalysed by steroid dehydrogenases [29]. There are two different 3-HSD known so far to catalyse the formation of either $3 \alpha$-hydroxysteroids, or $3 \beta$-hydroxysteroids. The $3 \alpha$-HSD isoform is expressed predominantly in the brain, prostate, liver, skin, lung, kidney, and gonads. 
Physiologically, this enzyme acts as an oxidoreductase (reductase-dehydrogenase) catalysing the reduction of the 3-ketogroup on steroids into a $3 \alpha$-hydroxygroup and vice versa. This enzyme is also able to metabolise many non-oestrogenic compounds thereby acting mainly as a dehydrogenase $[30,31,33]$. 3 $\beta$-hydroxysteroid dehydrogenase occurs in humans in two distinct forms, $3 \beta$-HSD- 1 and $3 \beta$-HSD-2. $3 \beta-H S D-1$ is found in the placenta, skin, mammary gland, prostate, and endometrium, as well as in breast cancer cells, whereas $3 \beta$-HSD- 2 prevails in the gonads and adrenals [15]. Human $3 \beta$-HSD-isomerases belong to the SDR (short-chain dehydrogenase/reductase) family, catalysing a dehydrogenase activity involving NADH as the co-factor [38]. PCR analysis demonstrated a moderate amount of $3 \beta$-HSD-1 RNA in human foetal liver [32], but reports on these enzymes in pig tissues are lacking.

Incubations with porcine liver microsomal or post-mitochondrial fractions indicate that $\alpha-\mathrm{ZOL}$ is the main metabolite of ZEA in pigs. However, at low concentrations of ZEA $(<100 \mu \mathrm{M})$, the ratio shifted towards higher amounts of $\beta-Z O L$, indicating the involvement of both isoenzymes in the hepatic biotransformation of ZEA. This observation was further substantiated by the observation that higher amounts of reduced metabolites of ZEA were produced by the microsomal fraction as compared to the post-mitochondrial fraction (at equal amounts of cellular protein). When calculating the $\alpha-$ ZOL/ $\beta-Z O L$ ratio in either fraction (see Tabs. I and II), it became obvious that at almost all tested concentrations of ZEA, the amount of both metabolites produced by microsomes was higher than the amount produced by the post-mitochondrial fraction, and that the amount of $\alpha$-ZOL exceeded that of $\beta-Z O L$. These findings suggest that the enzymatic activity of $3 \alpha-$ HSD and probably $3 \beta$-HSD varies in different subcellular fractions, i.e. occurring as microsomal and cytosolic forms [2], depending on the organ or part of the organ [27], and the animal species investigated. Indeed, it has been shown for example that cytosolic $3 \alpha-\mathrm{HSD}$ activity is greater than the microsomal one in the liver and skin of rats, while in humans and dogs microsomal $3 \alpha$-HSD activity is about one order of magnitude lower than the cytosolic activity in the liver and prostate [19, 33].

Further evidence for the involvement of $3 \alpha-\mathrm{HSD}$ in the conversion of ZEA in $\alpha-Z O L$ is provided by competition studies with porcine hepatic microsomes. In the presence of $5 \alpha$-androstanedione, a keto-steroid and prototypical substrate for $3 \alpha-\mathrm{HSD}$, the $\alpha-Z O L$ production was significantly inhibited. Also in the presence of pregnenolone, the apparent formation of $\alpha-\mathrm{ZOL}$ was inhibited, corresponding to the finding that pregnenolone can be a substrate for

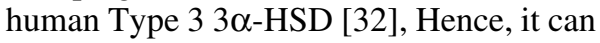
be concluded that in the pig liver the reduction of ZEA towards $\alpha$-ZOL is catalysed predominantly by microsomal $3 \alpha$-reductases. In contrast to the $\alpha$-ZOL production, the formation of $\beta$-ZOL by pig liver microsomes was only inhibited in the presence of pregnolonone, a typical endogenous substrate for $3 \beta$-HSD. The concentrationdependent inhibition of $\alpha$ - and $\beta$-ZOL production confirms that this inhibition is competitive. Further investigations are necessary to quantify enzyme expression in pig livers and to compare enzyme velocity in pig subcellular fractions with those in other animal species, to identify enzyme distributions in pig livers and to compare enzyme velocity in pig subcellular fractions with those of other animal species, including man.

In conclusion, the present experiments with the MCF-7 cell bioassay demonstrated the higher oestrogenic activity of $\alpha$-ZOL when compared to that displayed by the parent toxin or the $\beta$-hydroxylated metabolite. Moreover, the in vitro experiments with pig liver subcellular fractions showed the formation of $\alpha$-ZOL to be prevalent in this animal species. Taken together, the bioconversion to $\alpha$-ZOL has to be considered as a bio-activation step, which may together with the known enterohepatic recirculation 
of ZEA provide the mechanistic explanation for the high sensitivity of pigs towards feed materials, contaminated with the mycotoxin zearalenone.

\section{ACKNOWLEDGMENTS}

This research was supported financially by the Iranian Ministry of Sciences, Research, and Technology.

\section{REFERENCES}

[1] Ahamed S., Foster J.S., Bukovsky A., Wimalasena J., Signal transduction through the Ras/Erk pathway is essential for the mycoestrogen zearalenone-induced cellcycle progression in MCF-7 cells, Mol. Carcinog. 30 (2001) 88-98.

[2] Amet Y., Simon B., Quemener E., Mangin P., Floch H.H., Abalain J.H., Partial purification of 3 alpha- and 3 beta-hydroxysteroid dehydrogenases from human hyperplastic prostate. Comparison between the two enzymes, J. Steroid. Biochem. Mol. Biol. 41 (1992) 689692.

[3] Andersen H.R., Andersson A.M., Arnold S.F., Autrup H., Barfoed M., Beresford N.A., et al., Comparison of short-term estrogenicity tests for identification of hormone-disrupting chemicals, Environ. Health Perspect. 107 Suppl. 1 (1999) 89-108.

[4] Biehl M.L., Prelusky D.B., Koritz G.D., Hartin K.E., Buck W.B., Trenholm H.L., Biliary excretion and enterohepatic cycling of zearalenone in immature pigs, Toxicol. Appl. Pharmacol. 121 (1993) 152-159.

[5] Bories G.F., Perdu-Durand E.F., Sutra J.F., Tulliez J.E., Evidence for glucuronidation and sulfation of zeranol and metabolites (taleranol and zearalanone) by rat and pig hepatic subfractions, Drug. Metab. Dispos. 19 (1991) 140-143.

[6] Briske-Anderson M.J., Finley J.W., Newman S.M., The influence of culture time and passage number on the morphological and physiological development of Caco-2 cells, Proc. Soc. Exp. Biol. Med. 214 (1997) 248-257.

[7] Chang K., Kurtz H.J., Mirocha C.J., Effects of the mycotoxin zearalenone on swine reproduction, Am. J. Vet. Res. 40 (1979) 12601267.

[8] Dacasto M., Rolando P., Nachtmann C., Ceppa L., Nebbia C., Zearalenone mycotoxicosis in piglets suckling sows fed contaminated grain, Vet. Hum. Toxicol. 37 (1995) 359-361.
[9] Dees C., Foster J.S., Ahamed S., Wimalasena J., Dietary estrogens stimulate human breast cells to enter the cell cycle, Environ. Health Perspect. 105 Suppl. 3 (1997) 633-636.

[10] Devleeschouwer N., Legros N., Olea-Serrano N., Paridaens R., Leclercq G., Estrogen conjugates and serum factors mediating the estrogenic trophic effect on MCF-7 cell growth, Cancer Res. 47 (1987) 5883-5887.

[11] Diel P., Smolnikar K., Michna H., In vitro test systems for the evaluation of the estrogenic activity of natural products, Planta Med. 65 (1999) 197-203.

[12] Esquenet M., Swinnen J.V., Heyns W., Verhoeven G., LNCaP prostatic adenocarcinoma cells derived from low and high passage numbers display divergent responses not only to androgens but also to retinoids, J. Steroid Biochem. Mol. Biol. 62 (1997) 391-399.

[13] Gajecki M., Zearalenone-undesirable substances in feed, Pol. J. Vet. Sci. 5 (2002) 117122.

[14] Gao H., Bodine P.V., Murrills R., Bex F.J., Bilezikian J.P., Morris S.A., PTH-dependent adenylyl cyclase activation in SaOS-2 cells: passage dependent effects on $\mathrm{G}$ protein interactions, J. Cell. Physiol. 193 (2002) 10-18.

[15] Gingras S., Simard J., Induction of 3betahydroxysteroid dehydrogenase/isomerase type 1 expression by interleukin-4 in human normal prostate epithelial cells, immortalized keratinocytes, colon, and cervix cancer cell lines, Endocrinology 140 (1999) 4573-4584.

[16] Gloy J., Greger R., Schollmeyer P., Huber M., Pavenstadt H., Influence of cell culture conditions and passage number on the response of membrane voltage to ATP and angiotensin II in rat mesangial cells, Ren. Physiol. Biochem. 17 (1994) 62-72.

[17] Goya L., Feng P.T., Aliabadi S., Timiras P.S., Effect of growth factors on the in vitro growth and differentiation of early and late passage C6 glioma cells, Int. J. Dev. Neurosci. 14 (1996) 409-417.

[18] Huang W., Carlsen B., Rudkin G.H., Shah N., Chung C., Ishida K., Yamaguchi D.T., Miller T.A., Effect of serial passage on gene expression in MC3T3-E1 preosteoblastic cells: a microarray study, Biochem. Biophys. Res. Commun. 281 (2001) 1120-1126.

[19] Hudson R.W., Comparison of 3 alphahydroxysteroid dehydrogenase activities in the microsomal fractions of hyperplastic, malignant and normal human prostatic tissues, J. Steroid Biochem. 20 (1984) 829-833.

[20] Ju Y.H., Carlson K.E., Sun J., Pathak D., Katzenellenbogen B.S., Katzenellenbogen J.A., Helferich W.G., Estrogenic effects of extracts from cabbage, fermented cabbage, and acidified brussels sprouts on growth and 
gene expression of estrogen-dependent human breast cancer (MCF-7) cells, J. Agric. Food Chem. 48 (2000) 4628-4634.

[21] Kawabata Y., Tashiro F., Ueno Y., Synthesis of a specific protein induced by zearalenone and its derivatives in rat uterus, J. Biochem. (Tokyo) 91 (1982) 801-808.

[22] Kennedy D.G., Hewitt S.A., McEvoy J.D., Currie J.W., Cannavan A., Blanchflower W.J., Elliot C.T., Zeranol is formed from Fusarium spp. toxins in cattle in vivo, Food Addit. Contam. 15 (1998) 393-400.

[23] Kleinova M., Zollner P., Kahlbacher H., Hochsteiner W., Lindner W., Metabolic profiles of the mycotoxin zearalenone and of the growth promoter zeranol in urine, liver, and muscle of heifers, J. Agric. Food Chem. 50 (2002) 4769-4776.

[24] Kuiper G.G., Lemmen J.G., Carlsson B., Corton J.C., Safe S.H., van der Saag P.T., van der Burg B., Gustafsson J.A., Interaction of estrogenic chemicals and phytoestrogens with estrogen receptor beta, Endocrinology 139 (1998) 4252-4263.

[25] Kuiper-Goodman T., Scott P.M., Watanabe H., Risk assessment of the mycotoxin zearalenone, Regul. Toxicol. Pharmacol. 7 (1987) 253-306.

[26] Lowry O.H., Rosebrough N.J., Farr A.L., Randall R.J., Protein measurement with the Folin phenol reagent, J. Biol. Chem. 193 (1951) 265-275.

[27] Miles C O.A.F. Alistair L.W. Wilkins A.L., Neal R.T., Barry L.S., Ian G., Bryan G.S., Richard P.H., Ovine metabolism of Zearalenone to alpha-zearalanol (Zeranol), J. Agric. Food Chem. 44 (1996) 3244-3250.

[28] Mirocha C.J., Schauerhamer B., Pathre S.V., Isolation, detection, and quantitation of zearalenone in maize and barley, J. Assoc. Off. Anal. Chem. 57 (1974) 1104-1110.

[29] Olsen M., Kiessling K.H., Species differences in zearalenone-reducing activity in subcellular fractions of liver from female domestic animals, Acta Pharmacol. Toxicol. (Copenhagen) 52 (1983) 287-291.

[30] Penning T.M., 3 alpha-hydroxysteroid dehydrogenase: three dimensional structure and gene regulation, J. Endocrinol. 150 Suppl. (1996) S175-S187.

[31] Penning T.M., Pawlowski J.E., Schlegel B.P., Jez J.M., Lin H.K., Hoog S.S., Bennett M.J., Lewis M., Mammalian 3 alpha-hydroxysteroid dehydrogenases, Steroids 61 (1996) 508523.

[32] Pezzi V., Mathis J.M., Rainey W.E., Carr B.R., Profiling transcript levels for steroidog- enic enzymes in fetal tissues, J. Steroid Biochem. Mol. Biol. 87 (2003) 181-189.

[33] Pirog E.C., Collins D.C., Metabolism of dihydrotestosterone in human liver: importance of 3alpha- and 3beta-hydroxysteroid dehydrogenase, J. Clin. Endocrinol. Metab. 84 (1999) 3217-3221.

[34] Rutten A.A., Falke H.E., Catsburg J.F., Topp R., Blaauboer B.J., van Holsteijn I., Doorn L., van Leeuwen F.X., Interlaboratory comparison of total cytochrome P-450 and protein determinations in rat liver microsomes. Reinvestigation of assay conditions, Arch. Toxicol. 61 (1987) 27-33.

[35] Shier W.T., Shier A.C., Xie W., Mirocha C.J., Structure-activity relationships for human estrogenic activity in zearalenone mycotoxins, Toxicon 39 (2001) 1435-1438.

[36] Soto A.M., Sonnenschein C., Chung K.L., Fernandez M.F., Olea N., Serrano F.O., The E-SCREEN assay as a tool to identify estrogens: an update on estrogenic environmental pollutants, Environ. Health Perspect. 103 Suppl. 7 (1995) 113-122.

[37] Soto A.M., Fernandez M.F., Luizzi M.F., Oles Karasko A.S., Sonnenschein C., Developing a marker of exposure to xenoestrogen mixtures in human serum, Environ. Health Perspect. 105 Suppl. 3 (1997) 647-654.

[38] Thomas J.L., Mason J.I., Brandt S., Spencer B.R. Jr., Norris W., Structure/function relationships responsible for the kinetic differences between human type 1 and type 23 betahydroxysteroid dehydrogenase and for the catalysis of the type 1 activity, J. Biol. Chem. 277 (2002) 42795-42801.

[39] Trenholm H.L., Warner R.M., Fitzpatrick D.W., Rapid, sensitive liquid chromatographic method for determination of zearalenone and alpha- and beta-zearalenol in wheat, J. Assoc. Off. Anal. Chem. 67 (1984) 968-972.

[40] Ueno Y., Tashiro F., Alpha-Zearalenol, a major hepatic metabolite in rats of zearalenone, an estrogenic mycotoxin of Fusarium species, J. Biochem. (Tokyo) 89 (1981) 563-571.

[41] Weaver G.A., Kurtz H.J., Mirocha C.J., Bates F.Y., Behrens J.C., Robinson T.S., Gipp W.F., Mycotoxin-induced abortions in swine, Can. Vet. J. 19 (1978) 72-74.

[42] Yang H.H., Aulerich R.J., Helferich W., Yamini B., Chou K.C., Miller E.R., Bursian S.J., Effects of zearalenone and/or tamoxifen on swine and mink reproduction, J. Appl. Toxicol. 15 (1995) 223-232. 